\title{
A Reasonable Price for Electricity
}

\author{
Simone Pront-van Bommel ${ }^{1}$
}

Received: 5 February 2014 / Accepted: 20 August 2015 /

Published online: 6 February 2016

(C) The Author(s) 2016. This article is published with open access at Springerlink.com

\begin{abstract}
Over the past decade, consumers' electricity costs have risen disproportionally compared with the average inflation rate, mostly as the result of increased network tariffs and taxes. This development appears to be at odds with the stated purpose of introducing competition into the electricity sector through implementation of the EU Electricity Directive to realize benefits for end users in terms of lower prices as well as better quality of goods and services. This article discusses the conditions under which the price of electricity can be considered reasonable according to the Directive. The meaning of the term "reasonable" may depend on a number of factors, and it is necessary to distinguish between the various components of an energy bill. The various objectives of the directive could lead to diverging interpretations, even when applied to the same component of the bill, the supply price. According to the underlying market principle, reasonable may imply "economically efficient." However, in line with the principle of universal service for households, reasonable should be understood to mean "affordable." The article also examines the conditions under which a substantial rise of consumer energy costs due to increasing network tariffs can be justified. The focus of this article is on electricity, although, as stipulated under the Third Gas Directive, a consumer's right to pay a reasonable price, while enjoying universal service, applies equally to gas. Therefore, the observations outlined in this paper are relevant also for gas consumers.
\end{abstract}

Keywords Reasonable energy price $\cdot$ Regulation

\section{The Disproportionate Increase of Consumer Energy Costs}

The purpose of liberalizing the EU's electricity and gas sector was "to ensure that EU consumers receive the full benefits of market opening in terms of lower domestic bills for

Editors' Note: On 17 October 2015, Dr. Simone Pront-van Bommel, the author of this article, sadly passed away after it had been accepted for publication. In agreement with the University of Amsterdam's Centre for Energy Research, we are publishing this paper in memory of Dr. Pront-van Bommel.

Simone Pront-van Bommel

cve-fdr@uva.nl

1 Amsterdam Centre for Energy Research, Faculty of Law, University of Amsterdam, Amsterdam, Netherlands 
electricity and gas" through the introduction of competition and the "freeing of all electricity and gas consumers to choose their supplier" (European Commission 2001a, p. 33). The liberalization programme was carried out in phases. The first phase, which became effective on 1 July 2004, comprised the gradual opening of the market to facilitate the supply of energy to large-scale, industrial end-users ${ }^{1}$ and from 1 July 2004, at the latest, to all non-household customers. Subsequently, the energy sector was opened up for all end users, including households by the Second Electricity Directive and Second Gas Directive on 1 July $2007 .^{2}$ Competition is still regarded as a key objective of the Third Electricity Directive and the Third Gas Directive. ${ }^{3}$

Furthermore, as stipulated in both Directives, consumers are entitled to a reasonable energy price based on the right of universal service. Article 3 (3) of the Third Electricity Directive states that "Member States shall ensure that all household customers, and, where Member States deem it appropriate, small enterprises (namely enterprises with fewer than 50 occupied persons and an annual turnover or balance sheet not exceeding EUR 10 million), enjoy universal service, that is the right to be supplied with electricity of a specified quality within their territory at reasonable, easily and clearly comparable, transparent and non-discriminatory prices." Gas suppliers have a mandatory duty to inform all consumers with access to the gas grid of their right to be supplied with natural gas of a certain quality at a reasonable price, in conformity with national regulatory standards for gas supply (Annex I (1) (g) of the Third Gas Directive). From this, we can conclude that gas consumers' right of supply is to be seen in the light of a universal service in a way similar to that regarding electricity.

However, during the period between 2008 and 2012, nearly every Member State saw household electricity prices increase. On average, EU household electricity prices increased by more than $4 \%$ per year. Industrial electricity prices had gone up in that period by about $3.5 \%$ per year (European Commission 2014a, p. 9). ${ }^{4}$ Across the EU, gas prices for households appear to have increased by as much as $60 \%$ over a period of 10 years. This price increase has in general been higher than the current rise of retail price levels in most individual Member States (European Commission 2014a, p. 14). The final amounts on electricity bills show an increase nearly three times as high as the price rises of other goods and services. ${ }^{5}$ At first glance, this sharp increase of end-user energy prices seems particularly puzzling because it is out of line with the aim of liberalizing the energy sector and of creating a universal service. This article discusses whether this conclusion is correct, using the Third Electricity Directive as its basis, and examines what constitutes a reasonable energy price. In addition, if an energy

\footnotetext{
${ }^{1}$ Art. 19 of the Directive 96/92/EC of the European Parliament and of the Council of 19 December 1996 concerning common rules of the internal market in electricity, OJ L 27/20 and Art. 18 of the Directive 98/30/EC of the European Parliament and the Council of 22 June 1998 concerning common rules for the internal market in natural gas, OJ L 204/1.

2 Art. 2 (12) and 21 of the Directive 2003/54/EC of the European Parliament and of the Council of 26 June 2003 concerning common rules for the internal market in electricity and repealing Directive 96/92/EC, OJ L 176/37 and Art. 2 (28) and 23 of the Directive 2003/55/EC of the European Parliament and the Council of 26 June 2003 concerning common rules for the internal market in natural gas and repealing Directive 98/30/EC, OJ L 176/57. ${ }^{3}$ Directive 2009/72/EC of the European Parliament and of the Council of 13 July 2009 concerning common rules for the internal market in electricity and repealing Directive 2003/54/EC, OJ L 211/55 and Directive 2009/ 73/EC of the European Parliament and the Council of 13 July 2009 concerning common rules for the internal market in natural gas and repealing Directive 2003/55/EC, OJ L 211/94.

${ }^{4}$ See for gas: European Commission 2014a, pp. 72-73: More than $3 \%$ per annum on average for household consumers and about $1 \%$ for industrial end users during the 2008-2012 period.

${ }^{5}$ Price developments on the EU retail markets for electricity and gas 1998-2011. Retrieved from: http://ec. europa.eu/energy/observatory/electricity/doc/analysis_retail.pdf.
} 
price is considered unreasonable, we need to establish which measures are available in order to establish a reasonable price.

As the Third Electricity Directive does not define the term "reasonable," it will be necessary to interpret the term according to the text, requirements and objectives of the Directive. These include the stated purpose of a properly functioning competitive market or, in other words, of competition. Other objectives include maintaining a universal service and security of supply and establishing a sustainable energy sector. Security of supply concerns the continuous delivery of energy through networks. The delivery of energy depends on the continuous operation of a complex grid structure to deliver energy from production units to end-users. Furthermore, the environmental objective of the Third Package is relevant. Ways to protect our environment include energy savings, re-use, and production and consumption of renewable energy.

These objectives form part of the European legal framework. This can be deduced from, among other things, the fact that the Third Electricity Directive expressly requires the NRAs to include as part of their task any reasonable measures necessary to achieve the objectives stated in the Directive (Article 36 of the Third Electricity Directive). ${ }^{6}$ Therefore, NRAs are tasked, among other duties, to pursue both competition and consumer protection measures.

For purposes of this analysis, it should be noted that end-user electricity bills (like gas bills) are made up of several components. We shall therefore have to consider for each component individually whether the Third Electricity Directive's requirement of reasonableness applies and what it entails for the component in question. Therefore, the article defines the various components of electricity bills. Secondly, the article discusses whether these components are subject to competition. In so far, as this is the case, the meaning of "a reasonable price for energy" is interpreted in line not only with the stated purpose of a competitive market, but also with a requirement of a universal service. The article also discusses what may be regarded as reasonable with regard to the components of the energy bill that fall outside the scope of competition, insofar as the requirement applies also to those components. This concerns network tariffs in particular. Finally, this article discusses the public measures a Member State could take to mitigate any unreasonable adverse effects of increases of energy cost for consumers. A conclusion is then presented.

\section{Energy Bill Components}

The energy value chain consists of various components, including production, trading, supply, distribution and transport via a network. However, the liberalization of the energy sector applies only to the production, trading and supply segments. According to neoclassical economic theory, the supply price should be the result of competition and consequently, of the interaction of supply and demand. The supply price includes the price paid by the supplier for purchasing energy on the wholesale market and includes capital expenditures (CAPEX) and operating expenses (OPEX) of production units.

In addition to a supply price, the end user energy bill includes a regulated tariff for access to the network, for transport and distribution, and for network services. Market forces are not a

\footnotetext{
${ }^{6}$ See also Art. 40 of the Third Gas Directive.
} 
decisive factor in establishing and setting network tariffs since the energy transmission and distribution network services have remained outside the scope of liberalization (Künneke 1999). ${ }^{7}$ After all, electricity transmission and distribution systems are operated by legal monopolies (Cabau 2007; Energy Community Secretariat 2012, para. 3.2.1). The underlying premise is that a monopoly is necessary to guarantee the large, long-term investments required for network infrastructures, as these could not be properly ensured under competitive conditions. Operating several electricity networks within the same area is considered inefficient. The monopoly of transport and distribution system operators is subject to far-reaching regulation to prevent abuse.

The energy bill also comprises taxes, including energy tax and value added tax (VAT). According to the Energy Taxation Directive, ${ }^{8}$ Member States have a legal obligation to levy taxes on energy supply services. The implementation of energy tax regulations was intended to promote energy efficiency, among others, through the reduction of energy use. Requirements laid down in the Tax Directive consider energy sources as well as energy use regimes. The Directive provides Member States with ample latitude for national policies regarding the application of taxation, allowing a broad spectrum of general interest issues to be considered and prioritised. Member States are granted discretion for expanding the scope of the exemptions stipulated in the Tax Directive and, additionally, can exempt companies that supply renewable energy. This leaves room for considerations regarding environmental objectives to play a relevant role. National law establishes the levels of taxes and exemptions, and these are the result of a democratic process of public decision-making by legislative authorities of Member States taking into account various public interests such as energy efficiency and support for energy-intensive industries that are subject to strong international competition. This taxation law is intended to serve as a complementary measure to the European Emissions Trade System (EU ETS), according to which large producers of fossil energy are required to obtain emission allowances for production. The taxation of energy products and the cost of emission allowances may lead to a further increase of consumer energy prices since energy companies can be assumed to pass these on to end users.

The following two sections focus on the requirement of "reasonableness" of energy prices with regard to both supply price and network tariffs.

\section{Reasonable Supply Price}

From analyses presented previously, it follows that the way to define a reasonable price is primarily by reference to the stated objective of a competitive market only insofar as the supply price is concerned. Therefore, with regard to the supply price, we may interpret the meaning of reasonable in the light of the competition principle. Subsequently, the meaning of a reasonable price according to the principle of universal service as laid down by the Third Electricity Directive will be examined. This is in order to determine whether what is considered reasonable by reference of universal service is consistent with what is reasonable in terms of competitive market outcomes.

\footnotetext{
${ }^{7}$ The municipality of Feldheim provides a rare example of competing energy networks. Retrieved from: http:// www.huffingtonpost.com/2011/12/29/feldheim-germany-renewable_n_1173992.html.

${ }^{8}$ Council Directive 2003/96/EC of 27 October 2003 restructuring the Community framework for the taxation of energy products and electricity, OJ L 283/51.
} 


\section{Competition}

The market mechanism is said to establish price levels through the interaction between the forces of supply and demand (Brennan and Moehler 2010; Krugman et al. 2011). According to neoclassical economic theory, in a competitive market, the price mechanism will lead to optimised allocation and use of goods and services and, ultimately, maximum prosperity for energy consumers and lower prices helped by efficiency gains. Efficiency gains can include cost reductions through a more efficient operation of existing assets and through the use of cheaper or new and more efficient energy production technologies (Pollitt 2008, p. 4). The proper functioning of a market is measured by the intensity of competition in the marketplace (Belyaev 2011, p. 31). The intensity of competition depends, among other things, on the number of market players, including both suppliers and customers. There must be a sufficient number of suppliers, none of which represents a market majority (Belyaev 2011, p. 43). In addition, the market share of each player must be such that none of them can unilaterally set the rules and determine market outcomes. If a seller or buyer withdraws from the marketplace in a liquid market, this should not materially affect prices. This is a matter of market liquidity, which must be adequate.

By systematically keeping profit margins low whilst ensuring the best possible quality of the product or service at marginal production and delivery costs, a properly functioning market system allows prices to move towards an equilibrium. In other words, this approach supposes a correlation between competition and efficiency. In line with the economic approach to market mechanism, price movements induced by a competitive market may be considered to be reasonable under the Directive. The term reasonable in this sense refers to economically efficient. From the economic perspective, a robust competitive market, as envisaged by the Third Electricity Directive, could ensure that the best available mix of assets and suppliers is used to deliver electricity to meet the need of consumers in the most cost-efficient manner.

For all economic sectors, including the energy industry, the stated purpose of a competitive market has been expressed in the right to free movement of goods, services and capital as laid down in the Treaty on the Functioning of the European Union (Articles 26, 28, 56 and 63 of the Treaty). The reasoning is that any impediment to the free movement of goods, services and capital must be removed in order to create an internal market (Lenaerts and Van Nuffel 2011, p. 196). As such, the competitive market theory also determines the content of the European legal framework in energy. For instance, the competitive market theory forms the basis for conditions intended to protect consumers in Annex I to the Third Electricity Directive. These include a number of requirements regarding the content of supply contracts and accessible procedures for settlement of disputes. The contractual conditions for consumers, for example, must be fair and available in advance, and suppliers may unilaterally increase prices only under certain conditions. ${ }^{9}$ These requirements contribute towards consumer empowerment and seek to create an articulate and well-informed market party capable of making mature choices regarding suppliers and standing up for its rights, thus encouraging actual competition. For purposes of consumer protection, consumers are assumed to be prepared and capable of

\footnotetext{
${ }^{9}$ See also CJEU judgement of 21 March 2013, RWE Vertrieb AG/Verbraucherzentrale Nordrhein-Westfalen, C92/11, ECR nyr.; CJEU judgement of 23 October 2014, Technische Werke Schussental GmbH und Co KG/ Alexandra Schulz and Josef Egbringhoff/Stadtwerke Ahaus GmbH, joined cases C-359/11 \& C-400/11, ECR nyr.
} 
enjoying the benefits of a competitive market (Micklitz 2013, pp. 272, 291-273, 345). The requirements in the Annex intend to provide consumers the requisite means for this.

However, in practice, in many Member States, the operation of the free market is severely limited as a result of price regulation. Under these regulations, supply prices quoted to consumers are subject to supervision and approval by a public authority prior to their release. Even a decade after the first phase of liberalizing the energy sector, in a majority of the Member States supply, retail prices are regulated and price caps and other regulatory measures on EU incumbents are common. As of 2012, 18 Member States continue to regulate retail prices. Cyprus, France, Greece, Hungary and many other Member States apply rate-of-return regulation. Five other Member States, including Denmark, Estonia and Portugal, have set price caps (European Commission 2014a, pp. 31-32; European Commission 2012b, p. 15). Evidently, prices for energy have been artificially reduced by these caps (Energy Commission Secretariat 2012, p. 1). ${ }^{10}$ The following part will examine to what extent such price measures by Member States are consistent with the Third Electricity Directive.

\section{Public Service Obligations}

The Third Electricity Directive allows competition to be limited in certain cases, such as by the price measures mentioned earlier. After all, under European law Member States have discretionary powers (Article 3 (2) of the Third Electricity Directive) to impose public service obligations (PSOs) on energy companies and utilities in the general economic interest (European Commission 2013). This provision covers a range of varying general interests. According to the Third Electricity Directive, PSOs may relate to "security, including security of supply, regularity, quality and price of supplies and environmental protection, including energy efficiency, energy from renewable sources and climate protection." Although consumer protection is not explicitly stated in Article 3 (2) of the Directive, the Member States can also impose PSOs to protect consumers (Delvaux et al. 2012), in particular to ensure the individual consumer's right to be charged a reasonable price (European Commission 2001a; Energy Commission Secretariat 2012; ERGEG 2010). After all, according to the formulation of the provision in the Directive as confirmed also in the Federutility judgment ${ }^{11}$ discussed later on, the list of general interests for PSOs is not exhaustive.

The discretionary powers of Member States to regulate supply prices by price caps or other price measures are however limited by the criteria defined in the Directive and by the Federutility judgment. According to the Directive, such obligations "shall be clearly defined, transparent, non-discriminatory, verifiable and shall guarantee equality of access for electricity undertakings of the Community to national consumers." Also, Member States may impose these obligations only on energy companies if the general rules for free movement of goods and service are observed. According to general principles of EU law, these freedoms may in some cases be restricted, but only if certain criteria are met, as stated by the Federutility judgment. In this judgement, the Italian energy authority, the Autorità per l'energia elettrica e il gas, had introduced reference prices in agreement with the regulatory standards of national government energy policy. Customers were free to choose between the current market retail

\footnotetext{
${ }^{10}$ See for gas: EC 2014a, p. 92: The scope of price regulation in 15 Member States seems to be more limited than for electricity.

${ }^{11}$ CJEU judgement of 20 April 2010, Federutitity, C-265/08, ECR I-3377.
} 
value and the fixed maximum values set by the state. The majority of end users opted for the latter because the reference price was artificially kept below the market price. ${ }^{12}$

Under this jurisprudence, Member States must firstly ensure that the implemented price regulation is consistent with the provisions on the services of general economic interest and that the price regulation serves a public interest that falls under the scope of Article 3 (2). Member States have to weigh the various general interests and objectives and any price measure should be the result of balancing the different public interests and values, including the protection of consumers and providing universal service. Member States do retain a certain margin of discretionary authority to determine and prioritize their relevant public interest objectives. However, PSOs imposed by a Member State must satisfy the necessity requirement, which is derived from the EU law proportionality principle. ${ }^{13}$ According to this requirement, price ceilings are permitted only if there is no alternative, less far-reaching method to realize a reasonable price for end-users and if the fixed price imposition is of a temporary nature (European Commission 2013). Furthermore, the imposition of the price measure must be clearly defined and must comply with the criteria of objectivity and transparency. Moreover, energy companies must be ensured a non-discriminatory access to the retail market. Price regulation may also vary depending on the purpose and given circumstances in the Member States involved so that a Member State may be compelled to differentiate between various groups of end-users. This could imply that a price ceiling regulation may need to be imposed in favour of only a specific group of end-users, such as households. In other words, given the Federutility judgment, an implementation of price regulations that lacks differentiated targeting strategies aimed at the different end-user segments may be in conflict with the proportionality principle.

According to the Federutility judgment, price regulation can be legal if it serves to protect consumers against excessive supply prices. Excessively high prices can be caused by a lack of market liquidity, as was the case in Federutility itself. In practice, many Member States do not have a liquid market, with by far the largest part of the market being served by only a small number of enterprises. This is partly due to the limited number of transmission interconnections between Member States. Regulation of electricity end prices is therefore a common indicator of insufficient competition in the wholesale market (Pollitt 2008, p. 7).

In line with the stated purpose of a properly operating competitive market, price regulation is permitted only in the event that competition has not yet reached a sufficient level (and then only for the duration of such a situation of limited competition). It is therefore also essential for Member States to introduce measures to promote competition. The aim is to ultimately render price regulation by Member States superfluous. To promote this objective, the Third Electricity Directive introduced stricter requirements over and above the Second Electricity Directive with regard to the unbundling of energy companies, the expansion of transport system interconnections and the improvement of market transparency (European Commission 2012a; Lecoque 2011). In line with such developments, the Commission has started various infringement proceedings (Energy Commission Secretariat 2012). ${ }^{14}$ According to this reading,

\footnotetext{
$\overline{12}$ The ruling relates to the supply of gas as well as to the Second Gas Directive, but it is of equal significance for both the electricity sector and the rules under the Third Electricity Directive.

${ }^{13}$ See also CJEU judgement of 1 July 2014, Ålands Vindkraf, C-573/12, ECR nyr. and CJEU judgement of 21 December 2011, ENEL, C-242/10, ECR I-13665.

${ }^{14}$ Press Release, Energising Europe: A real market with secure supply, 19 September 2007. Retrieved from: http://europa.eu/rapid/press-release_IP-07-1361_en.htm?locale=en.
} 
the Federutility judgment is in agreement with the competitive market theory mentioned previously.

\section{Universal Service}

The next important step is to determine what exactly the requirement of a reasonable supply price based on universal service entails, and whether this is consistent with the concept of a reasonable price based on economic criteria as discussed previously. It is therefore necessary first to explain the scope of universal service under the relevant directives.

The term "universal service" concerns the provision of certain services of a specified quality at an affordable price and in conformity with nation-specific circumstances. Such services should be made available to all consumers and end-users within the territory of the respective Member State, regardless of its geographical location. Universal services provide warranties for the fulfilment of basic human needs, such as supplies of electric power and gas, which are deemed to socially impact the wellbeing of citizens. Universal services include all those areas of the society and the economy without which the consumer cannot participate in the normal economic, social and political life, such as energy and telecommunications (Micklitz 2013, p. 309). Universal service also implies that consumers living on or falling below the poverty line must also be able to purchase energy. This consideration shows that universal service is not aimed solely at the availability of energy, but also at meeting the requirement of affordability (European Commission 2001a, p. 29). The affordability of electric power, amongst others, strengthens community empowerment and economic and social cohesion across Member States (European Commission 2003, para. 3.1.4). It is then left to the discretion of individual EU Member States to define what an affordable retail price is and to prioritize appropriate consumer protection standards. ${ }^{15}$ In any case, the term reasonable will need to be interpreted while bearing in mind that all the people must be able to participate in economic, social and political life. This depends on various factors, not just the price of supplying electricity, but also for example on income and the local cost of living. Member States have a responsibility to consider these various aspects.

The reading of reasonable as affordable agrees with the description given by the Universal Service Directive ${ }^{16}$ of a universal service for the market of electronic communication networks and services, a market similar to the electricity market. In both cases, the service depends on access to a network and constitutes an essential service to EU citizens. The Universal Service Directive explicitly states that "Member States shall ensure that the services set out in Chapter II of this Directive are made available at the quality specified to all end-users in their territory, independently of geographical location, and, in the light of specific national conditions, at an affordable price" (Article 3 (1) of the Universal Service Directive). This is all the more important for electricity because it is an essential service for EU citizens without

\footnotetext{
${ }^{15}$ Recital 50 of Third Electricity Directive speaks of "fair prices"; see also Recital 7 of Third Gas Directive.

${ }^{16}$ Directive 2002/22/EC of the European Parliament and of the Council of 7 March 2002 on universal service and users' right relating to electronic communications networks and services (Universal Service Directive), OJ L $108 / 51$.
} 
which they would not have other basic services, such as telecommunications, at their disposal.

\section{Various Types of End Users}

From the perspective of universal service, it is essential to distinguish between the various profiles of end-users (Lavrijssen 2014; Pront-van Bommel 2011a). In any event, all households are entitled to a reasonable price for electricity as part of a universal service. The electricity supply to households is regarded as customer purchases of electricity to be used for home consumption of energy only and therefore not intended to be utilised either in commercial or in professional activities (Article 2 (10) of the Third Electricity Directive ${ }^{17}$ ). In addition, according to Article 3 (3), individual Member States have discretionary powers to extend the scope of this definition to include small and medium-sized enterprises (defined as having up to $50 \mathrm{FTE}$ employees or an annual turnover of up to $€ 10$ million) and organizations in the regulatory provisions of national energy legislation.

In contrast, large-scale customers do not qualify for reasonable market price conditions under these provisions of the Third Electricity Directive. However, large-scale users may be able to force down the price of electricity, for instance by using their countervailing market power or competition law in the event that competition is distorted by the abuse of a dominant market position, or by means of antitrust suits and unfair competition claims (Cameron 2007; Hariharan and Ghaya 2010). In this respect, the regulatory scope of competition law extends beyond the provisions that follow from the above-mentioned principles of EU energy legislation and includes potential large-scale end users.

\section{Vulnerable Consumer}

The Third Electricity Directive in particular has adopted warranties addressing the needs of vulnerable consumers who constitute a more specifically defined consumer segment (Article 3 (7) of the Third Electricity Directive ${ }^{18}$ ). The Third Electricity Directive stipulates that Member States have to define the term consumer vulnerability, which among other criteria refers to energy poverty.

In this respect, a fundamental public interest is at stake, as access to energy is a sine qua non for preparing food, maintaining health, giving and receiving education, undertaking economic activities, etc. In short, access to energy for humans is crucial for satisfying all basic human needs and for the realization of fundamental rights including participation in economic activity and as such in overcoming poverty and social isolation (Bradbrook and Gardam 2010; Bradbrook 2006; Tully 2006) The reason for protecting vulnerable consumers is that access to electricity can be considered a human right, given its vital role for realising other fundamental rights such as dignity, health and education, even if the right to have access to energy as such is not explicitly mentioned in the EU Charter of Fundamental Rights.

At the very least, the right to have access to energy can be supposed to be an inseparable component of socio-human rights (Bradbrook 2006). According to the Charter, EU citizens are in any case entitled to human dignity. A life without access to an appropriate electricity source to fulfil basic human needs is degrading and could be seen to violate the right to dignity

\footnotetext{
${ }^{17}$ See also Art. 3 (3) of the Third Gas Directive.

${ }^{18}$ See also Art 3 (3) of the Third Gas Directive.
} 
(Articles 1) (Aviles 2012). Furthermore, the right to energy of a specified quality must also be considered as a service of general economic interest, as provided under the Treaty and EU legislation based on it, which Member States have to recognize and respect (Article 36 of the Charter). This means that electricity ought to be within the financial reach of each EU citizen. The Charter is legally binding for EU institutions and national governments.

The presence of such binding legal provisions does not alter the fact that, today, energy poverty is a major problem. Almost $11 \%$ of the EU population were unable to keep their homes adequately warm in 2012. The situation was even worse for low-income households, which tend to spend proportionally more on electricity, gas and heating-related fuels than medium-income or high-income households (European Commission 2014a, p. 125). In the $\mathrm{EU}$, as a whole, $24.4 \%$ of the population living in low-income households are unable to adequately heat their homes. The situation varies across Member States. In Bulgaria, for instance, only $46.5 \%$ of the people can properly warm their homes (European Commission 2014a, p. 127). The issue of energy poverty has therefore increasingly featured on the EU agenda in recent years (Thomson and Snel 2013). It is therefore especially important to find out which provisions are available to Member States for ensuring reasonable energy costs.

\section{Reasonable According to Universal Service}

In conclusion, according to the principle of universal service, Member States are obliged to implement appropriate measures to maintain a high standard of consumer protection, in particular by adopting a socially oriented approach towards low-income households and by reducing consumer vulnerability in general. The right to have access to energy also includes affordability and reliability of the electricity supply (Bradbrook and Gardam 2010).

Considered from the perspective of universal service, the term reasonable should be interpreted in line with the principles of "fairness" and "social justice" rather than the principle of a competitive market according to which a reasonable price is seen as a economically efficient result of competition. After all, taking into account the previously mentioned factors contributing towards the realization of a more competitive market, a high supply price could be economically efficient and may be defined as reasonable insofar as it is the outcome of sufficient competition and includes a limited operating profit margin. However, from the perspective of universal service, the term reasonable would not be necessarily synonymous with "affordable for households," particularly where vulnerable consumers are involved. In a liquid market, high end-user prices for the supply of energy could well be the result of increased purchase prices paid by energy-producing companies on the commodity wholesale market to cover the replenishment of raw materials such as oil or other necessary investments made in a particular year. An increasing supply price can also be caused by passing on the cost of the taxation of energy products or of $\mathrm{CO}_{2}$ emission rights, as such passing on would occur in accordance with competitive market principles. However, passing these costs on to endusers may substantially affect families living on a restricted household budget and may cause electricity to become unaffordable (Pront 2012). In such a case, the electricity price would be at odds with the universal service principle. This reflects a conflict between diverging objectives of the Directive, giving cause for fundamental criticism against the economic approach as described. The fundamental criticism concerns the absence of a way to judge fair distribution in relation to well-being and the failure to address such issues as fairness, equality, justice, human rights and equity. Economic efficiency does not automatically mean that the market has resulted in an ethically acceptable allocation of goods and values, and separately 
from these, to well-being (Baujard 2013; Feintuck 2010; Hammond 1992; Sen 1987, pp. 7, $28-32,78)$.

The above analysis suggests that there may not be a competitive market within which a reasonable price is achieved. In such an event, price control actions by the Member States may be legal according to the Federutility judgement. However, even in a competitive market, the price may be unreasonable, albeit in terms of fairness and based on ethical considerations. The underlying thought is that the distribution of goods and means should be considered unfair from a point of view of human rights. In such an event, given the proportionality principle as defined by the judgment, Member States should consider the availability of any other methods that may safeguard an affordable energy price and that are less detrimental to the competitive market mechanism.

According to the Third Electricity Directive, Member States "shall take appropriate measures, such as formulating national energy action plans, providing benefits in social security systems to ensure the necessary electricity supply to vulnerable customers, or providing for support for energy efficiency improvements, to address energy poverty where identified, including in the broader context of poverty" (Article 3 (8)). Actions that may contribute to limiting the total price of energy include the introduction of measures promoting flexible electricity use, the introduction of smart meters and the promotion of local renewable energy generation near end-user locations that can contribute to the efficient operation of distribution systems and can help to keep a grip on the rise of network costs. Network tariffs should reflect any network cost savings resulting from demand-side improvements, demand-response measures and distributed generation, including savings from reduced cost of delivery or network investments and optimised network operation under the Energy Efficiency Directive. ${ }^{19}$ The large-scale implementation of smart metering and sophisticated internet communication technology (ICT) is mandatory, subject to a positive result of the compulsory cost/benefit analysis of Member States (Article 9 of the Energy Efficiency Directive). One function of smart metering is to provide households with accurate and current information of their energy consumption in order to stimulate awareness and ultimately bring about efficient energy use and energy savings.

On the basis of the previous statement, we can conclude that in a liquid market, a general price measure will usually be at odds with the principle of proportionality. Other measures will then be needed to establish a reasonable cost of energy. It will be also necessary to define the group of consumers for whom the price of electricity is prohibitive. They might consist only of a limited group of consumers. Furthermore, a prohibitive energy price could also be the result of high network tariffs and taxes, in which case supply price regulation will not bring a solution.

\section{Reasonable Network Tariffs}

From the previous statement, it becomes clear that the retail price forms only part of the total amount to be paid for electricity (European Commission 2014b; European Commission 2012 b, p. 34, Fig. 5). A prohibitive energy price could also be the result of high network

\footnotetext{
${ }^{19}$ Directive 2012/27EU of the European Parliament and of the Council of 25 October 2012 on energy effiency, amending Directives 2009/125/EC and 2010/30/EU and repealing Directives 2004/8/EC and 2006/32/EC, OJ L $315 / 1$.
} 
tariffs and taxes, in which case supply price regulation will not bring about a solution. Moreover, network costs and taxes represent a large part of an end-user's energy bill. On top of that, their part in the energy bill has increased considerably in recent years. In 2008, taxes and levies on average accounted for $9 \%$ of household energy costs (European Commission 2014a, p. 23). Network charges also constitute a substantial part of final energy prices, in 2012 reaching $50 \%$ in the case of households, and $56 \%$ in the case of industrial consumers. The taxes and levies component of the EU weighted average price went up by $36.5 \%$ in 2012, whilst it accounts on average for $30 \%$ of the final price, up from $26 \%$ in 2008. During the 2008-2012 period, network costs on average went up by around $18.5 \%$ for households and $30 \%$ for industrial consumers (European Commission 2014b, p. 7). Hence, it is worth underscoring that most of a consumer's energy bill falls outside the scope of market liberalization and competition principles.

Moreover, network tariffs and taxes are the components that have driven up household energy bills the most. Whereas the energy component remained the most important element in the end consumer bill, its relative share registered significant decreases (more than $10 \%$ for industrial consumers and about half as much for households). As the relative share of network costs remained relatively stable, representing about a third of the bill, it was the taxation component that filled the gap left by the supply of energy component. At the same time, their share also varies per Member State. In the case of electricity prices paid by households, in 2012, the energy component was between 3.2 Eurocent/kWh (Romania) and 20.4 Eurocent/ $\mathrm{kWh}$ (Cyprus) and accounted for between $18 \%$ (Denmark) and $82 \%$ (Malta) of the household electricity price. In 2008, taxes and levies represented on average $26 \%$ of the median household bill, being as low as $5 \%$ for Malta, the UK and Lithuania, and accounting for more than half of the bill in Denmark (52 \%). In 2012, the relative share of taxes reached $30 \%$ on average, ranging from $5 \%$ in the UK to close to $30 \%$ in Austria, Estonia, Finland, France, Italy and Sweden, and reaching 43, 46 and $56 \%$ respectively in Portugal, Germany and Denmark. Also, the impact of the different components on the final amount of the energy bill varies according to the type of end user. The actual value of the imposed cost components is significantly higher for households than for large industrial customers. On the other hand, large customers may be partially or completely exempt from certain network charges, taxes and levies (European Commission 2014b; European Commission 2014a, pp. 15-24 and 33; European Commission 2012a, 2012b). ${ }^{20}$

\section{Requirements Regarding Network Tariffs}

Given the need to protect consumers against excessively high energy bills, it is essential to consider the requirements imposed by the Third Electricity Directive with regard to the tasks of network operators and also the level of network tariffs, as they determine what is considered reasonable in this context. According to the Third Electricity Directive, energy networks must at least be accessible to anyone on the basis of non-discriminatory, objective and transparent conditions. These criteria help to safeguard the right of third party access (Article 32 (1) of the Third Electricity Directive). Network operators are then bound to connect consumers and other market parties in accordance with these criteria (Article 3 (3) of the Third Electricity Directive). Furthermore, network operators should also guarantee the continuity of supply.

${ }^{20}$ See for gas: European Commission 2014a, pp. 79-85. 
In addition, tariffs or pricing methodologies applied by network operators must be fixed or approved by NRAs. We have already seen that NRAs are bound to fulfil their legal regulation task in line with the requirements and objectives laid down in the Third Electricity Directive (Article 37). These objectives concern not only access to the market, but also the security of supply and energy-efficiency as well as the integration of large and small-scale production of electricity from renewable energy sources and the distributed generation in both transmission and distribution networks (Article 37 (d) of the Third Electricity Directive). What is reasonable in this context is also determined by the principles of good governance that apply to NRAs. Although NRAs have discretionary power when approving and setting a network tariff, its implementation is subject to the restrictions imposed by such principles. These concern, among other matters, the independence, transparency (Article 35 sub 4 of the Third Electricity Directive) and accountability of supervision. These principles have partly been embedded in the European Directives, such as for regarding the requirements of transparency and motivation of supervision decisions they entail. ${ }^{21}$ The principle of proportionality is another principle of good governance, based on which NRAs must balance the public interests (Karpen 2010; Lenaerts and van Nuffel 2011; LavrijssenHeijmans 2006; European Commission 2001b, pp. 7-8).

Therefore, given the absence of competition, for the establishment of legal tariffs, reasonable means something other than "economically efficient." A reasonable increase in network tariffs could be defined as a proportionate outcome of the weighing of various public values. In the longer term, as the priorities of the objectives change, the balance of interests might tip the other way. This implies that various criteria for the reasonableness of network tariffs apply, ranging from operating efficiency, moderate cost recovery, benchmark-based evaluation and fair surcharges to investments guaranteeing security of supply. In recent years, objectives regarding energy efficiency and continuity of supply have gained importance. Therefore, an increase in network tariffs could be reasonable to safeguard security of supply or to realize an environmental objective, as explained in the following section.

\section{Investing in Transport and Distribution Systems}

Environmental objectives and security of supply both require substantial financial investments towards innovation in the transmission and distribution infrastructure. Infrastructural investments are necessary as current assets become outdated. Furthermore, the existing energy infrastructure needs innovative adaptation. Network operators must invest in the construction of modern transport and distribution systems to ensure that the new generation of renewable energy producers has unrestricted and easy access to the transmission and distribution system. Investing in innovative adaptation not only helps to achieve environmental objectives, but is also considered important to ensure security of supply. One aspect of supply security associated with network innovation concerns the legal responsibility of transmission and distribution system operators to ensure an uninterrupted energy supply. This supply warranty is jeopardised in the event of a mass rollout of network connections for producers of renewable energy. This is due to the fact that renewable energy depends on intermittent sources and the fact that we have no cost-efficient means (as yet) of storing electricity (Bradbury et al. 2014). A critical condition for energy transport systems to maintain security of supply is to balance demand and

${ }^{21}$ Art. 35 sub 4 and Art. 37 sub 16 of the Third Electricity Directive and Art. 39 sub 4 and Art. 41 sub 16 of the Third Gas Directive. 
supply in order to prevent outages. A higher level of flexibility of energy is therefore required to facilitate the effective integration of intermittent energy production installations, such as through a dynamic demand response to real-time electricity supply conditions, features that go beyond the technical ability of conventional network infrastructures. To develop further flexibility of demand on a distributed level, a large-scale roll-out of smart grid technology equipped with smart meters and integrated, innovative internet technology (IT) applications is essential (Erlinghagen and Markard 2012; Pront-van Bommel 2011b).

The expenditure involved in such adaptations is enormous. It is estimated that in order to achieve the $20 \%$ EU energy efficiency target for 2020, investments amounting up to 1000 billion euros will be needed towards a full integration of innovative energy infrastructure across EU Member States, both in transmission and distribution network infrastructure and in the renewable energy production capacity (European Commission 2010). The tremendous investments in transmission and distribution systems will have to be paid largely from network tariffs. These investments will presumably cause regulated network tariff rates to rise further.

Based on the above, we can conclude that according to the Third Electricity Directive, higher energy costs could be justified as reasonable in terms of security of supply and environmental objectives. At the same time, these higher energy costs may be in conflict with consumer interests and affordability. For instance, these interests were recently the topic of heated debates in Germany on the feed-in system. ${ }^{22}$ Under the feed-in system, small and large generators of renewable energy, such as produced by wind generators and solar panels, have a right to be paid a long-term, guaranteed, cost-based purchase price that includes a reasonable return for the energy delivered to the network. The purpose of this provision is to enable investors to help develop technologies. The compensation rates should make it possible for an installation - when managed efficiently - to be operated cost-effectively based on the use of state-of-the-art technology and depending on the renewable energy sources naturally available in a given geographical environment. In many other Member States local producers of renewable energy have already been entitled to fixed feed-in tariffs (Mendonça et al. 2010). This legal provision aims to stimulate the production and use of renewable energy in response to the underlying environmental targets. Feed-in rates in Germany paid by energy system operators are subsequently passed on to end-users. This feed-in system is under discussion due to the fact that the impact of this particular cost aspect on consumer energy bills affects vulnerable consumers much more than other market participants (Hünter 2012). ${ }^{23}$

\section{Conclusions}

A reasonable energy price is guaranteed under EU legislation, and affordable energy is crucial for satisfying all basic human needs. For this reason, the article examines whether recent increases in consumer energy bills may be regarded as reasonable according to the Third

\footnotetext{
${ }^{22}$ Act on granting priority to renewable energy sources (Erneuerbare-Energien-Gesetz-EEC), 1 January 2012.

23 The feed-in system in Germany was recently overhauled, and most new producers must now offer the renewable energy on the market to subsequently receive a supplementary premium to cover the cost. In 2014 this law was reformulated in stricter terms for new producers. As from 1 August 2014, producers of renewable energy, with the exception of small-scale producers, in principle no longer receive a feed-in tariff, and instead must offer their energy for sale on the market. They may also receive a supplementary remuneration linked to the feed-in tariff.
} 
Electricity Directive, which guarantees a consumer's right to a reasonable price as part of universal service. However, the Directive fails to define what is meant by reasonable.

The article seeks to fill in this gap based on the various objectives encapsulated in the Third Electricity Directive, starting with the objective of competition. After all, the original aim of introducing competition through the Directive was to give consumers the benefit of lower prices as well as higher quality goods and services as a result of supply and demand interaction. In line with the stated purpose of the competition principle, the term reasonable refers to a price that is the result of an efficiently operating market.

However, in most Member States, market effects have been drastically restricted by price regulation, even though Member States may only resort to price regulation insofar as this is in line with the legal requirements for imposing PSOs. Under the Third Electricity Directive a Member State has the discretionary power to impose PSOs, including price regulation, on energy companies, on condition that these are consistent with the EU legal framework. The PSO must be aimed at safeguarding a public interest included in the Directive, other than competition. Price regulation may therefore be permissible to offer protection to consumers. In addition, the PSO must satisfy the requirements of necessity and subsidiarity, which are derived from the principle of proportionality. Price regulation may be seen as compatible with the stated purpose of a more competitive market if it is used to reduce high supply prices resulting from an insufficiently liquid market. Even so, when considering regulation from this perspective, Member States will subsequently need to introduce measures to promote competition as much as possible, among others, by the unbundling of energy companies, the expansion of transport system interconnections, and the improvement of market transparency.

It is a remarkable fact that, although most Member States have drastically limited competition by introducing price regulations, ultimately, this has not protected end-users from a disproportionate increase in electricity costs. To understand this contradiction, the article analysed the various components that make up an energy bill, such as supply price, network tariffs, taxes and levies. Of these, only the supply price is subject to competition in the current environment.

The major drivers of the disproportionate rise of end-user electricity costs appear to be increasing taxes, levies and network tariffs. These comprise a large part of an energy bill. In view of this development, we can explain the combination of the substantial rise of consumer energy costs and, simultaneously, price regulation. Given the variety of components making up an energy bill, price regulation can protect endusers from rapid supply price increases, but not from any rise in the other electricity bill components. On the other hand, a substantial increase in network tariffs and taxes could be in line with other public interests that are also promoted by the EU legislation. An increase in network tariffs could for example be considered reasonable to achieve security of supply and environmental protection. Security of supply may force Member States into massive investments to update transport and distribution systems to cope with large volumes of renewable energy. Member States have discretionary power to fulfil these tasks and in line with this to weigh and prioritize different public interests.

Interpreting the concept of a reasonable price in terms of fairness and social justice produces a different result, for in that case reasonable equates affordable. Although the Third Electricity Directive does not explicitly state that the total energy bill must be reasonable in the 
sense of affordable, the requirement for Member States to ensure that this is the case may be deduced from the general directive requirement to provide special protection for vulnerable consumers. This requirement for Member States can also be deduced from the EU Charter. The analysis of the various electricity bill components shows that for energy to become affordable, additional provisions will be needed, in particular where vulnerable consumers are involved (European Commission 2014a, pp. 242-245; European Commission 2013). These must include measures that serve to limit the amount of the total energy bill, such as the introduction of smart meters. In addition, Member States have discretionary authority to set their own energy access criteria out of the multitude of EU regulatory provisions that address fuel poverty. These may include provisional measures with regard to social security assistance and support schemes as well as subsidies for improving the energy efficiency of public housing (European Commission 2003, para. 3.1.4).

Various Member State bodies may be charged with monitoring the increase of the total enduser electricity cost and introducing pre-emptive measures. The tasks of the NRAs are to supervise a reasonable supply price and to regulate network tariffs. The purpose of tariff regulation can also be the stimulation of an efficient use of networks. A firm foundation in national energy law is therefore needed to give NRAs sufficient authority to weigh the various public interests in relation to their regulatory policy. Further, other measures that may contribute towards the affordability of electricity, such as domestic thermal insulation, form part of government policy.

The above conclusions are consistent with the statement by the Council of European Energy Regulators in its "2020 vision for Europe's energy customers," 24 in which it articulated that the long-term trend for energy prices is to increase, and that this trend makes it all the more important that the underlying reasons for such price increases are made transparent and fair to all. In the opinion of the Council, however, the problem is that regulators consider themselves primarily responsible for ensuring the proper functioning of energy markets and for regulating the "natural monopoly" element of the overall energy value chain, i.e., the transmission and distribution network tariffs. These elements constitute only a portion of the final price paid by customers, while other elements are subject to various government policies such as taxation and renewable energy support.

Open Access This article is distributed under the terms of the Creative Commons Attribution 4.0 International License (http://creativecommons.org/licenses/by/4.0/), which permits unrestricted use, distribution, and reproduction in any medium, provided you give appropriate credit to the original author(s) and the source, provide a link to the Creative Commons license, and indicate if changes were made.

\section{References}

Aviles, L. A. (2012). Electric energy access in European Union law: A human right? The Colombia Journal of European Law online, 19, 1-8. Available at http://www.cjel.net/wp-content/uploads/2013/04/Aviles-Final. pdf.

Baujard, A. (2013). Welfare economics [Working Paper]. Groupe d'analyse et the théorie économique lyon—st. Étienne. Available at http://halshs.archives-ouvertes.fr/docs/00/90/69/07/PDF/1333.pdf.

Belyaev, L. S. (2011). Electricity market reforms. New York: Springer Science and Business MediaLLC.

$\overline{{ }^{24} \text { Ref. C12-SC-02-04, } 24 \text { April } 2012 .}$ 
Bradbrook, A. J. (2006). Access to energy services in a human rights framework. Human Rights Quarterly, 28, $389-415$.

Bradbrook, A. J., \& Gardam, J. G. (2010). Energy and poverty: A proposal to harness international law to advance universal access to modern energy services. Netherlands International Law Review, 57, 1-28.

Bradbury, K., Pratson, L., \& Patiño-Echeverri, D. (2014). Economic viability of energy storage systems based on price arbitrage potential in real time U.S. electricity markets. Applied Energy, 114, 512-519.

Brennan, G., \& Moehler, M. (2010). Neoclassical economics. In M. Bevir (Ed.), Encyclopedia of political theory, vol. II (pp. 946-951). California: SAGE Publications.

Cabau, E. (2007). The definition of the relevant market. In C. W. Jones (Ed.), EU energy law, vol II, EU competition law and energy markets (pp. 28-29). Leuven: Claeys \& Casteels.

Cameron, P. D. (2007). Competition in energy markets, law and regulation in the European Union (Chapter 13). New York City: Oxford University Press.

Delvaux, B., Hunt, M., \& Talus, K. (Eds.). (2012). EU energy law and policy issues, vol. III (pp. 63-98). Cambridge: Intersentia.

Energy Community Secretariat (2012). Regulated energy prices in the energy community - state of play and recommendations for reform. Vienna: Energy Community Secretariat, 25 May.

ERGEG. (2010). Status review of end-user price regulation as of 1 January 2010. Brussels: European Regulators Group for Electricity and Gas.

Erlinghagen, S., \& Markard, J. (2012). Smart grids and the transformation of the electricity sector: ICT firms as potential catalysts for sectoral change. Energy Policy, 51, 895-906.

European Commission. (2001a). Proposal for Directive of the European Parliament and of the Council amending Directives 96/92/EC and 98/30/EC concerning common rules for internal market in electricity and natural gas. Brussel: European Commission. COM (2001) 125 final.

European Commission. (2001b). European governance. A white paper. Brussel: European Commission. COM (2001) 428 final.

European Commission. (2003). Green paper on services of general interest. Brussel: European Commission. COM (2003) 270 final.

European Commission. (2010). Energy infrastructure priorities for 2020 and beyond-A blueprint for an integrated European energy network. Brussel: European Commission. COM (2010) 677 final.

European Commission. (2012a). Making the internal energy market work. Brussel: European Commission. COM (2012) 663 final.

European Commission. (2012b). Working group report on transparency in EU energy retail market. Report prepared for the 5th Citizens' Energy Forum. Brussel: European Commission.

European Commission. (2013). Communication from the Commission on delivering the internal electricity market and making the most of public intervention. Brussel: European Commission. C (2013) 7243 final.

European Commission. (2014a). Energy process and costs report. Brussel: European Commission Staff. SWD (2014) 20/2 final.

European Commission. (2014b). Energy prices and costs in Europe. Brussel: European Commission. COM (2014) $21 / 2$ final.

Feintuck, M. (2010). Regulatory rationales beyond the economic: In search of the public interest. In R. Baldwin, M. Cave, \& M. Lodge (Eds.), The Oxford handbook of regulation (Chapter 3). Oxford: University Press.

Hammond, P. J. (1992). Credible liberalization: Beyond the three theorems of neoclassical welfare economics. An invited address to the Tenth International Economic Association World Congress in Moscow. Retrieved from: http://homepages.warwick.ac.uk/ ecsgaj/CredLib.pdf.

Hariharan, S., \& Ghaya, K. (2010). Competition law in the energy sector: The European experience. European Energy and Environmental Law Review, 21, 197-202.

Hünter, M. (2012). Institut der deutschen Wirtschaft Köln, Verteilungswerkungen des EEG. "Wer profitiert, und wer muss zahlen?". Pressekonferenz 17 Berlin. Berlin, Statement

Karpen, U. (2010). Good governance. European Journal of Law Reform, 12(1-2), 16-31.

Krugman, P., Wells, R., \& Graddy, K. (2011). The essentials of economics, chapter III. New York: Worth Publishers.

Künneke, R. W. (1999). Electricity networks: How 'natural' is the monopoly? Utilities Policy, 8(2), 99-108.

Lavrijssen, S. (2014). The different faces of energy consumers. Journal of Competition Law and Economics, 10(3), 257-292.

Lavrijssen-Heijmans, S. (2006). Independent competition supervisors, regulatory powers and good governance. Den Haag: Boom Juridische Uitgevers.

Lecoque, D. (2011). Ownership unbundling of electricity transmission networks. European Energy and Environmental Law Review, 5, 207-230.

Lenaerts, K., \& van Nuffel, P. (2011). European union law. London: Sweet \& Maxwell. 
Mendonça, M., Jacobs, D., \& Sovacool, B. (2010). Powering the green economy. The feed-in tariff handbook. New York: Earthscan.

Micklitz, H. W. (2013). Do consumers and businesses need a new architecture of consumer law? A thought provoking impulse. Yearbook of European Law, 32(1), 266-367.

Pollitt, M. (2008). Foreword -liberalisation and regulation in electricity systems: How can we get the balance right? In F. P. Sioshansi (Ed.), Competitive electricity markets: design, implementation, performance. Oxford: Elsevier.

Pront, S. (2012). A fair price for electricity. Amsterdam: University Press.

Pront-van Bommel, S. (2011a). Putting the consumer at the centre? In S. Pront-van bommel (Ed.), The consumer and the other side of the electricity market (pp. 19-61). Amsterdam: Centrum voor Energievraagstukken UvA.

Pront-van Bommel, S. (2011b). Smart energy grids within the framework of the third energy package. European Energy and Environmental Law Review, 20, 32-44.

Sen, A. (1987). On ethics and economics. Oxford: Blackwell Publishing.

Thomson, H., \& Snel, C. (2013). Quantifying the prevalence of fuel poverty across the European Union. Energy Policy, 52, 563-572.

Tully, S. (2006). The human right to access electricity. The Electricity Journal, 19(3), 30-39. 